\title{
FILM AS A MEDIA USED BY TEACHERS TO TEACH WRITING FOR TERTIARY LEVEL STUDENTS
}

\author{
Ardayati ${ }^{1}$ \\ STKIP PGRI Lubuklinggau \\ ardayati470@yahoo.com ${ }^{1}$ \\ Submit, 20-04-2018 Accepted, 09-06-2018 Publish, 09-06-2018
}

\begin{abstract}
The aim of this research was to find out whether or not it was significantly effective to use film as a media in teaching writing for tertiary level students. This study used pre-experimental method which was focused on writing skill at the eleventh grade students of Senior High School Tugumulyo. The writer formulated two hypotheses; they were null hypothesis (Ho) and the alternative hypothesis (Ha). There were 352 students from nine classes as the population of this study. The sample was taken through cluster random sampling. The result was XI IA.2 class which consisted of 37 students. In this case, the writer collected the data by using writing test. Based on the findings, the result showed that $t_{\text {obtained }}$ was 6.38 where $t_{\text {table }}$ was 1.697. It showed that $t_{\text {obtained }}$ was higher than $t_{\text {table }}\left(t_{\text {obtained }}>t_{\text {table }}\right)$. Finally, the writer concludes that it was significantly effective to use film as media in teaching writing at the eleventh grade students of Senior High School Tugumulyo.
\end{abstract}

Keywords: teaching writing, film, media.

\section{INTRODUCTION}

In English teaching and learning process, writing becomes a crucial skill which should be understood by students. In writing activities, students are guided by the teacher how to generate ideas and develop sentences into good paragraphs. Writing has crucial beneficial for students. By writing, students can share what they have on their mind and develop their great idea in written form and give message from what they write. Writing activities motivates students to always think critically and be confidence to discuss and write their point of view on papers. Their writing result gives motivation and spirit for others. So, it can be concluded that writing gives positive impact for students in teaching and learning process because they are free to write down what on their minds are.

After having interview with the teacher of English at SMAN Tugumulyo, the facts show that students had difficulties when they wrote a paragraph in English. It is caused by limited of vocabulary mastery. All students are non native 
speakers and it is rather difficult for the students to explore their idea into written form. Actually, they have their idea on their mind but when they should write down in English, it becomes a serious problem for them to translate into English. It means that students had lack of vocabulary. Second, students are difficult to develop their idea when they are going to write. There are many topics in writing class and it is a must for the teachers to ask students' prior knowledge about the topics.

The students enjoy learning process when the teacher can use the media effectively and ask students to discuss together. When the students are motivated, they do not only love the materials but they also get the point and find out valuable lesson from the teacher. Since most students are not motivated to learn language, they are not interested in following any kind of guidance given by teachers, except copying down notes that will help in passing the examinations. It will be an ironic problem when the students have no any motivation in writing class.

One of media can be used by the teacher in teaching writing is film. Film is one of effective medium which can be used in teaching writing. Film explore experience uniquelly and students adore films. They are so interesting and focused on what they watch because film is such a great media which can bring them in an awesome place to explore experience. Film serves a similar function of traditional fairy tales, folk songs, or other oral storytelling traditions, but with a unique ability to combine multiple stimuli into a single and powerful entity (Glover, 2009:7). Film has a power to hypnotize students. By watching film, students will have good motivation to write their point of view and idea. They will think critically and can not stop writing about new things.

When watching a film, Different dimention is appeared and unique view will be seen by students. Students do not just listen to the sound but students are also served by seeing motion pictures . Motion pictures talk to the students in a great way and influence them to think directly about the condition around them. This enables viewers to connect with the information in a way that might vary from person to person, but ultimately resulting in a higher percentage of people learning from a single source. In addition Glover (2009:10) states that Film, when it utilizes all of its potential elements, touches on a variety of components that stimulate learning.

\section{LITERATURE REVIEW}

\section{The Basic Concept of Teaching}

Teaching is a process of sharing, discussing and understanding material in or otside the classroom. Teacher and students do interaction, giving questions and suggestion, discussing cases together, concluding the material and applying what 
they have discussed in their social life. As it is stated by Anderson (2001:3) that teaching is an intentional and reasoned act. Teaching is intentional because we always teach for some primarily to facilitate student learning. Teaching is guided students to be a better person. Teaching is not just about the activities which involves in the classroom but teaching a way of guiding students to interact, help, appreciate and discuss their perspective in positive way.

Teaching is focused on students, which is the teacher who serves as guide in learning process but the students who assume some responsibility for how much learning takes place (Larsen, 2007:10). Teacher give an opportunity to the students to argue, discuss, explain, complain, lead, read and answer case based on the clues given by the teacher. Teacher is as a fasilitator, motivator, conselor and a good model in teaching process. Thus, Saleh (1997:34) states that teaching is mainly a way of guiding students to obtain the amount and a quality of experience which help best to develop of teaching is guiding and facilitating learning enabling the learners to learn setting conditions for learning.

According to Brown (2000:7), teaching is guiding and facilitating, learning, enabling the learner to learn, setting the conditions for learning. It means a teacher can play the roles of a facilitator, guide, motivate, and manager. As facilitator, the teacher provides facilities such as circumstances, equipment, aids, etc. As a guide, the teacher shows or helps learners to learn how to do something and understand knowledge. The students have no opportunity to interact with the teacher and the teacher is also not in position to motivate the students to learn the language. Learning is two way process and the constant exchange of ideas makes the classes interesting. This unfortunately is lacking in the present scenario. Teachers should be friendly with the students and try to maintain a healthy relationship with the students. As a result, the students don't hesitate to come up with their doubt as they know that the teacher will treat the problems very sympathetically. A motivator means the teacher stimulates the interest of learner, and as a manager, the teacher arranges information and environment for student to learn.

In teaching language, teachers need some instruction to teach well. Robert Gagne proposed a series of events which follow a systematic instructional design process that share the behaviorist approach to teaching. There are seven steps in teaching, they are; a) inform students of the objectives, b) stimulate recall of prior learning, c) present the contents, d) provide learning guidance, e) elicit performance, f) provide feedback, g) assess performance.

\section{The Crucial of Teaching Writing}

According to Brown (2000:7), teaching is guiding, facilitating, learning, enabling the learner to learn, set the conditions for learning. It means a teacher can 
play the roles of a facilitator, guide, motivate, and manager. As facilitator, the teacher provides facilities such as circumstances, equipment, aids, etc. As a guide, the teacher shows or helps learners to learn how to do something and understand knowledge. The students have no opportunity to interact with the teacher and the teacher is also not in position to motivate the students to learn the language. Learning is two way process and the constant exchange of ideas makes the classes interesting. This unfortunately is lacking in the present scenario. Teachers should be friendly with the students and try to maintain a healthy relationship with the students. As a result, the students don't hesitate to come up with their doubt as they know that the teacher will treat the problems very sympathetically. A motivator means the teacher stimulates the interest of learner, and as a manager, the teacher arranges information and environment for student to learn. According to Anderson (2001:3), teaching is an intentional and reasoned act. Teaching is intentional because we always teach for some primarily to facilitate student learning. Teaching is reasoned because what teachers teach their students is judged by them to be worthwhile.

In teaching language, teachers need some instruction to teach well. Robert Gagne proposed a series of events which follow a systematic instructional design process that share the behaviorist approach to teaching. The following are nine steps in teaching process: a) gain attention of the students, b) inform students of the objectives, c) stimulate recall of prior learning, d) present the contents, e) provide learning guidance, f) elicit performance, g) provide feedback, h) assess performance

Writing is organization of four sentences into a text, into a coherent whole which is an explicit as possible and complete in its self, that we are able to communicate successfully with our reader through the medium of writing. Sometimes writing comes easily, if we are in the right mood or have a clear and perhaps pressing need to express something, but as rule it requires some conscious mental effort. We think out sentences and consider various ways of combining and arranging them. In addition, Saleh (1997:15) stated that writing is the fourth or the last skill the learner of English has to develop, even though it is the hardest of the language skill to acquire.

However, writing is clearly much more than the production of graphic symbols. It is a highly complex skill involving the integration of visual, meteoric and conceptual abilities. It is actually an expressive form of the graphic symbol system used for conveying thoughts, feelings, and ideas. Here are some teaching writing problems (Bryne: 1993:4): 


\section{Psychological problems}

Speech is natural and normal medium communication for us in most circumstances and accustoms us both to having someone physically present when we use language and getting feedback of some kind. Writing on other hand, is essentially a solitary activity and the fact that we are required to write on our own, without the possibility of interaction or the benefit of feedback, in itself makes the act of writing difficult.

\section{Linguistics problems}

Oral communication is sustained through a process of interaction. Because speech is normally spontaneous, we have little to pay attention either to organizing our sentences structure or to connecting our sentences to some extent the latter is maintained through the process of interaction. We repeat, backtrack, and expand and so on, depending on how people react to what we say. Incomplete and even ungrammatical utterances usually pass unnoticed. As we know, we also have a considerable range of device at our disposal to help get our meaning across. In writing, we have to compensate. We have to keep the channel of communication open through our own effort and to ensure, both through choice of sentence structure and by the way our sentences are linked together and sequenced, that the text we produce can be interpreted on its own.

\section{Cognitive problems}

People grow up learning to speak and in normal circumstances spend much of our time doing it. We also appear to speak without much conscious effort or thought and generally we talk because we want to about matter which are of interest or relevant to us socially or professionally. Writing, on the other hand is learn through a process of instruction. People have master the written form of the language and to learn certain structures which are less used in speech or perhaps not used at all, but which are important for effective communication in writing. People also have to learn how to organize our ideas in such a way that they can be understood by a reader who is not present and perhaps by a reader who is not known us. Finally, writing is a task which is often imposed on us, perhaps by circumstances. This not only has a psychological effect. It may also cause a problem in term of content what to say. Being at loss for ideas is a familiar experience to most of us when we are obliged to write.

According to Chin (1990:11) defines writing as a way communicating, information, ideas and feelings in written symbols. Furthermore, Rooks (1988:15) states that the aim of writing is communication. When people write, they want to give their ideas and information to their readers. So, teaching writing is not a 
simple way for teacher. The teacher should be able to manage the materials and the class.

\section{The Importance of Teaching Media}

Using various kinds of media in the classroom has always been a challenge, and how to bring these media in the classroom is more than a challenge. Students and teachers should be able to use in their classrooms different media through different technologies. Media is a supporting equipment for the teachers to enable them in explaining the materials attractively. What will be happen in the classroom when an attractive teacher use a media in teaching and learning process and bring it in a positive way and ask students to interact with the media? The class will be more alive with a great atmosphere in the classroom.

Students enable teachers to meet various needs and interests of their students. In addition, by using media teachers could get some advantages. They are the following:

a. Media provide huge information, they motive students to speak and help them integrate listening, reading, talking and writing skills, through various kind of activity.

b. Teaching through media presentation there is more communication and collaboration among students, while working with the page of book is more individual, less collaborative and less interactive.

c. Teachers can exploit a piece of learning material offered by various media in several different ways through: analyzing a text in book, reading and generating ideas from a text in newspaper or magazine, watching and discussing a TV program or a movie, classroom presentations, exercises and activities using various kinds of media, pair and group work, reconstructing the text based on the above information brought from different media, engaging students in useful writing and revision activities, etc.

There are several the advantages of using media in teaching, there are:

a. Media is increased the learners' experiences.

b. Media is reached everything out of the class, such as: markets, stations, harbors, bacteria, virus, etc.

c. Media is created the possible direct interaction between learners and their environment

d. Media is produced some observation done by the learners to achieve the teachers' aims.

e. Media is keeping the basic, concrete and real concepts of the teaching.

f. Media is aroused the learners' motivation to learn.

g. Media is integrated the experience from the concrete things to the abstract one.

h. Media is avoided the learner bored. 
i. Media make the learners easily to understand the instructional materials.

j. Media is made the teaching and learning process more systematic.

According to Riyana (2012:93) there some kinds of media education among others are:

\section{Audio Media}

Audio media is tool to convey messages to be delivered in the form of auditory symbols, verbal and nonverbal. Audio media for teaching is a material that contains a message in the form of auditory, which can stimulate the thoughts, feelings, concerns and willingness of the students. Kinds of audio media are: Radio education, Audio tape recording, telephone and compact disc (CD). There are some advantages of audio media, following:

a. It is easy to move.

b. Can be used in conjunction with radio recorder, so it can be repeated or played back.

c. Can stimulate active participation of hearing students, as well as to develop the imagination as writing, drawing and so on.

d. Students can focus like reading poetry, literature, music and language drawing.

The teachers should think how to help student teachers to use Media successfully in their future career, especially think of what is practically hidden behind them. It has immense potential as an instructional tool. In addition, media education is important because it develops students' creative powers for those images, words and sounds that come to the students from various Media. Thus, creating more active and critical media users, who will always be more demanding in the future. Media Education has to do with film and television, press and radio, their impact on the students' progress. It has to do with what to teach through media, when and how. Its aim is to enable students to develop critical thinking, analyzing and reflecting on their experiences while using various means of Media.

\section{Visual Media}

Visual media which means all the props used in the process of learning that can be enjoyed through the eye senses. There are some kinds of visual media: images or photos, sketch, diagram, chart, cartoons, poster, map and globe, flannel board, bulletin boards. Visual media serves to channel messages from the source to the receiver. The message will be delivered poured into visual symbols. In addition, the function of the visual media is to attract attention, serving to clarify ideas, illustrate or embellish fact that may be quickly forgotten if no visualized. 


\section{Audio Visual Media}

Audio visual equipment's is modern instructional media in accordance with the times the progress of science and technology, including that can be seen and heard. Audio visual media is a media intermediary or the use of materials and absorption through sight and hearing so as to establish conditions to enable the pupils to acquire knowledge, skills, or attitudes. According to Riyana (2012: 41) there are some kinds of audio visual media

a. Audio visual media movement, for example, television, video tape and film.

b. Audio visual media silence, for example, film strip voice, sound slide and comic voice.

c. Media audio semi motion, for example, media board.

d. Media visual motion, for example, silent film.

\section{Procedure of Teaching Writing through Film}

Teaching writing through film can be implemented by the following steps;

a. The teacher plays the film

b. The teacher and students watch the film

c. The teacher explains about material of narrative text

d. The teacher asks the students to write a narrative text based on the film.

e. The teacher gives the test to the students to write narrative text based on the topic that is choseen by the students.

\section{RESEARCH METHOD}

\section{Research Design}

The writer applied a pre-experimental with one group pre-test and post-test design. Dealing with this method, Fraenkel and Wallen (1990:235) state that preexperimental is useful ways of getting preliminary information on study questions. In this study the writer used one group pre-test-poest-test design. The design involved only an experimental group.

\section{Population and Sample}

The population was 355 students. Arikunto (2010:174) state that sample is a part of representative of population investigated. The writer used cluster random sampling.. XI IPA 2 was as the sample of this study. It consisted of 37 students.

Table 1. Population of the Study

\begin{tabular}{ccc}
\hline No & Classes & Number of students \\
\hline 1 & XI IPA 1 & 40 \\
\hline 2 & XI IPA 2 & 37 \\
\hline 3 & XI IPA 3 & 38 \\
\hline
\end{tabular}




\begin{tabular}{clc}
\hline 4 & XI IPA 4 & 40 \\
\hline 5 & XI IPA 5 & 40 \\
\hline 6 & XI IPS 1 & 39 \\
\hline 7 & XI IPS 2 & 38 \\
\hline 8 & XI IPS 3 & 40 \\
\hline 9 & XI IPS 4 & 40 \\
\hline & Total & $\mathbf{3 5 2}$ \\
\hline
\end{tabular}

\section{Technique for Collecting Data}

To collect the data, the writer used written test as the instrument; the test was given before and after the treatment. The instruments were two parallel tests, namely pre-test and post-test. The writer used the same material in the pre-test and in the post-test. Arikunto (2010:223) stateS that test is questions or exercises used to the students' skill, knowledge, and intelligence, attitude of an individual or group. The data collected through written test in the form of essay in narrative text that consisted of 100-150 words. The time was allocated for the students to do the test is 90 minutes.

\section{Technique for Analyzing Data}

There was be two test and administered in analyzing the data. First, the data concern with the pre-test scores. Second, the data concerned with the scores of the students in the post-test. Third, the marker in this study is using two raters. There were the English teacher and the writer himself. There were steps to be used for analyzing the data obtained, they were:

Individual score

Table 2. Scale Range and Category of Writing

\begin{tabular}{ccccc}
\hline \multirow{2}{*}{ Element } & \multicolumn{4}{c}{ Scale rang and category } \\
\cline { 2 - 5 } & $\begin{array}{c}\text { Excellent to } \\
\text { very good }\end{array}$ & $\begin{array}{l}\text { Good to } \\
\text { average }\end{array}$ & Fair to poor & Very poor \\
\hline Content & $25-23$ & $22-20$ & $19-17$ & $16-0$ \\
\hline Organization & $25-23$ & $22-20$ & $19-17$ & $16-0$ \\
\hline Structure & $25-23$ & $22-20$ & $19-17$ & $16-0$ \\
\hline Vocabulary & $15-14$ & $13-12$ & $11-10$ & $9-0$ \\
\hline Mechanics & 10 & $19-18$ & $7-6$ & $5-0$ \\
\hline
\end{tabular}


Conversion of the score

Table 3. The Conversion of MMC Range

\begin{tabular}{ll}
\hline MMC Range & Qualification \\
\hline $0-73$ & Failed \\
\hline $74-100$ & Passed \\
\hline Matched $t$-test &
\end{tabular}

The formula was presented below :

$t_{o b t}=\frac{\overline{x_{2}}-\overline{x_{1}}}{S_{\bar{D}}}$

Where :

$\mathrm{t}_{\text {obt }} \quad$ : The t-obtain

$\overline{x_{2}} \quad$ : The student's Mean Score in Post-test

$\overline{x_{1}} \quad$ : The students' Mean score in Pre-test

$\overline{S D} \quad$ : The Standar Errors of Differences

$\overline{S D}$ obtained by using the following formula

$$
\overline{S D}=\frac{S D}{\sqrt{n}}
$$

SD calculated by using the following formula:

Where :

$$
S D=\frac{\sqrt{\sum D^{2}-(1 / n)\left(\sum D\right)^{2}}}{n-1}
$$

n : Number of students

D : Difference of students' scores

\section{FINDING}

The data obtained from the written test in the pre-test analyzed from the structure (S), Vocabulary (V), Organization (O), Content (C), and Mechanics (M). the scores were obtained by adding the result of first rater by the second rater, and the dividing into 2. After being analyzed, the researcher looked for highest score, the lowest score, and average score of each student for pre-test and post-test.

In addition, the data do not only interpreted through the score obtained in the pretest and post-test but the data also analyzed in the process of learning and capability of students in doing their task in this study. It is crucial to prove the progress of the students ability. The students' score were analyzed by observing 
how they can process verbal and quantitative information, interprets data, solve problems and think critically.

\section{The Students' Score in Pre-test}

The writer gave students a pre-test then got students' score. The number of the students who took pre-test was 37 students. When the writer gave the pre-test to the students, some of them were difficult to start writing as the task to finish. They could not express their ideas in English well. Furthermore, the result of the pre-test can be seen in the appendix B.

The result of pre-test scores revealed that highest score was 91 which were reached by two students and lowest score was 40 reached by one student. The students' score was compared to MMC score in the following conditions: (1) the students' scores were determined as "passed" qualification when their scores were equal or exceeded 74. In contrast, the students' scores were considered "failed" when their scores were lower than 74 .

\section{The Students' Score in Post-test}

The researcher scored the students' writing result based on five criteria, they are; 1) Content; the clear content of composition and showing knowledge of subject, 2) organization: fluent expression, integration of sentence by sentence and paragraph by paragraph, 3) vocabulary; choice and usage appropriate idiom or word, 4) structure or language use, construction rules of the sentence or appropriate grammatical, 5) mechanic, mastery of spelling, punctuation, capitalization, and paragraphing. (Heaton,1988:146)

The students' writing was scored by two raters. Then, the students' score was analyzed by adding the result of calculation from first rater and second rater after that the scores were divided by 2 . The result of the students' in post-test war compared to MMC. It can be seen in appendix B. In the post-test, the higher score was 94 reached by one student, and the lowest score was 41 reached by one student, while the average score was 77,59. In the post-test there were 27 students who were in the "passed" qualification. However, there were still 10 students who in "failed" qualification.

\section{The result of Normality Testing in Pre-test}

Based on the calculation of normality test in the pre-test, the table of the list frequency of observation and expectation of the students' scores, the researcher found out that $\mathrm{X}_{\text {obtained }}^{2} 4.819$ with degree of freedom $(\mathrm{df})=5(6-1)$. Since level is $95 \%(0.05)$, and the $X^{2}$ table $=11.070$. The data is normal because $\mathrm{X}_{\text {obtained }}^{2}=4.819<\mathrm{X}_{\text {table }}^{2}=11.070$ 


\section{The Result Of Normality in Post-test}

Based on the calculation of normality in post-test, the table of the list frequency of observation and expectation of the students' score, the researcher found out that $\mathrm{X}^{2}{ }_{\text {obtained }}=8.353$ with degree freedom $(\mathrm{df})=5(6-1)$. Since level is $95 \%(0.05)$, and the $X^{2}$ table $=11.07$. So, can conclude was normality because $\mathrm{X}_{\text {obtained }}^{2}=8.353<\mathrm{X}_{\text {table }}^{2}=11.070$.

\section{Matched t-test}

After theresearcher calculated the students' score in both pre-test and posttest, the writer calculated the matched t-test to find out whether or not the writing through film as media to the eleventh grade students of SMA Negeri Tugumulyo in academic year 2016/2017. The writer found that the result of matched t-test calculation indicated that the $\mathrm{t}_{\text {obtained }}$ was 6.377 . This score was much higher than the t-critical value; that was 1.697.

Based on the data (see in the appendix), it was found out that the number of students (N) was 37, the sum of different (D) was 307, and the squared $\left(\mathrm{D}^{2}\right)$ was 5085 .

From the matched t-tests calculation above showed that $\mathrm{t}_{\text {obtained }}$ was 6.38 and the $t_{\text {table }}$ in level of significant $95 \%(0.05)$ with degree of freedom (df) 36 ( $37-1)$ is 1.697 . It means that $t_{\text {obt }} 6.377$ was higher than $t_{\text {table. Furthermore, the null }}$ hypothesis (Ho) was rejected and the alternative hypothesis (Ha) was accepted.

\section{DISCUSSSION}

Based on the research result of investigation, it can be supposed that it was significantly effective to teach writing through film as media to tertiary level students. It can be prooved by the students' average score before and after they were taught by using film. In pre-test students' average score was 69.30 and and 77.59 in post-test.

Before teaching the students by using film, the researcher gave a pre-test with purpose to get students' score in writing. The result of pre-test scores revealed that highest score was 91 and lowest score was 40. After giving pre-test, the researcher taught tertiary students by using film as media. As Glover (2009:10) states that Film, when it utilizes all of its potential elements, touches on a variety of components that stimulate learning.

The students responded well when they were treated by using film in teaching writing. Almost of the students got more attention and they were interested in watching the film. After they watched the film, they got more and new information and they got refresh to take their new ideas. Furthermore, the writer gave post-test after the treatment and the result of post-test showed that the students' writing was improved. In the post-test, the highest score was 94 reached 
by one student and the lowest score was 41 reached by one student. Based on the researcher's treatment result, it was showed that students' writing achievement was increased because the students enjoyed while learning English through film as media.

Finally, from the matched t-test calculation showed that $\mathrm{t}_{\mathrm{obt}}$ was 6.38 and critical value at significance level of 0.05 with degree freedom 36 (37-1) was 1.697. it means that the $t_{\text {obt }}$ was higher than critical value. Furthermore, the null hypothesis (Ho) was rejected and alternative hypothesis (Ha) was accepted. This indicated that it was significantly effective film as media to teach writing to tertiary level students.

\section{CONCLUSION}

The researcher concludes that it is significantly effective to use film as a media to teach writing subject. This conclusion is derived from the following indicators:

1. The students' average score in the post-test was higher than the average score in the pre-test. The students' average score in the pre-test is 69.30 and the students' average score in the post-test is 77.59.

2. The result of the matched t-test calculation showed that the $t_{\text {obt }}$ is higher than $\mathrm{t}$-table. The $\mathrm{t}_{\mathrm{obt}}$ is 6.38 , while the $\mathrm{t}$-table is 1.697 . It meant that the null hypothesis (Ho) is rejected and automatically the alternative hypothesis (Ha) is accepted.

\section{REFERENCES}

Anderson, (2001). Listening. Oxford: Oxford University Press

Arikunto. (2010). Prosedur Penelitian Suatu Pendekatan Praktik. Jakarta:PT RINEKA CIPTA.

Brown, D.H. (2000). Principles of Language Learning and Teaching: $4^{\text {th }}$ NY: Addison Wesley Longman Inc.

Byrne, D. (1993). Teaching Writing Skills. Essex: Addison Wesley Longman Ltd. Chin, B. (1990). On Your Own: Writing Process. Engelwood Cliff, NY: Prentice Hall, Inc.

Fraenkel \&Wallen. (1990). How to Design and Evaluate Research in Education. New York: McGraw-Hill, Inc.

Glover, K.L. (2009). Connection: Making sense of the world Around us (the Use of Music in Documentary Films). Montana: Montana State University.

Larsen, F. (2007). Practical English Language Teaching: Young Learners. Singapore: McGraw-Hill.

Riyana, C. (2012). Media Pembelajaran. Jakarta: DIRJEN Pendidikan Islam Kementrian Agama RI.

Rooks. (1998). Discovery in Academic Writing. Boston, MA: Heinle

Saleh, Y. (1997). Methodology of TEFL in the Indonesian Context. Palembang: Sriwijaya University 